\title{
Cadmium toxicity causes oxidative stress and induces response of the antioxidant system in cucumber seedlings
}

\author{
Jamile F. Gonçalves ${ }^{1}$, Alexssandro G. Becker ${ }^{2}$, Denise Cargnelutti ${ }^{1}$, Luciane A. Tabaldi ${ }^{2,4}$, Luciane \\ B. Pereira' ${ }^{1,3}$, Vanessa Battisti ${ }^{1}$, Rosélia M. Spanevello ${ }^{1,3}$, Vera M. Morsch ${ }^{1,3}$, Fernando T. \\ Nicoloso $^{2,4 *}$ and Maria R.C. Schetinger ${ }^{1,3 * *}$
}

${ }^{1}$ Departamento de Química. ${ }^{2}$ Departamento de Biologia. ${ }^{3}$ Programa de Pós-Graduação em Bioquímica Toxicológica. ${ }^{4}$ Programa de Pós-Graduação em Agronomia. Centro de Ciências Naturais e Exatas, Universidade Federal de Santa Maria, 97105 -900 Santa Maria, RS, Brasil *,**Corresponding authors:respectively ftnicoloso@yahoo.com and mariashetinger@gmail.com

Received: 11 September 2007; Returned for revision: 10 October 2007; Accepted: 08 November 2007

In this study, the effects of cadmium (Cd) on lipid peroxidation, electrolyte leakage, protein oxidation, ascorbate peroxidase (APX; E.C. 1.11.1.11), catalase (CAT; E.C. 1.11.1.6) and superoxide dismutase (SOD; E.C. 1.15.1.1) activities, and ascorbic acid, non-protein thiol groups and total soluble protein contents in cucumber seedlings (Cucumis sativus L.) were investigated. Seedlings were grown in vitro in an agar-solidified substrate containing four Cd levels as $\mathrm{CdCl}_{2}(0,100,400$, and $1000 \mu \mathrm{mol}$ $\mathrm{L}^{-1}$ ) for $10 \mathrm{~d}$. The lowest $\mathrm{Cd}$ level decreased the malondialdehyde concentration. Electrolyte leakage increased only at $1000 \mu \mathrm{mol}$

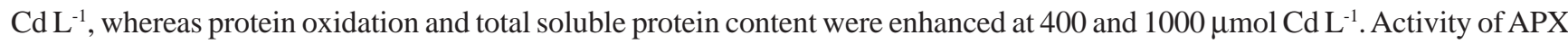
was inhibited while the activities of CAT and SOD were increased at all Cd concentrations. Ascorbic acid was enhanced at 400 and $1000 \mu \mathrm{mol} \mathrm{Cd} \mathrm{L}{ }^{-1}$ whereas non-protein thiol groups were increased at all Cd supplies. The results evidence the importance of the enzymatic and non-enzymatic antioxidant system in response to cadmium toxicity in cucumber seedlings. Key words: antioxidant enzymes, ascorbic acid, Cucumis sativus, heavy metal, lipid peroxidation, protein oxidation

Toxicidade de cádmio causa estresse oxidativo e induz resposta do sistema antioxidante em plântulas de pepino: No presente estudo, os efeitos do cádmio (Cd) sobre a peroxidação lipídica, o extravazamento de eletrólitos, a oxidação protéica, a atividade das enzimas peroxidase do ascorbato (APX; E.C. 1.11.1.11), catalase (CAT; E.C. 1.11.1.6) e dismutase do superóxido (SOD; E.C. 1.15.1.1) e as concentrações de ácido ascórbico, de grupos tióis não-protéicos e de proteínas solúveis totais foram investigados em plântulas de pepino (Cucumis sativus L.). As plântulas foram cultivadas in vitro em um substrato solidificado com ágar contendo quatro concentrações de $\mathrm{Cd}$ na forma de $\mathrm{CdCl}_{2}\left(0,100,400\right.$ e $\left.1000 \mu \mathrm{mol} \mathrm{L}^{-1}\right)$, durante $10 \mathrm{~d}$. A menor concentração de Cd diminuiu a concentração de aldeído malônico. O extravazamento de eletrólitos aumentou somente em 1000 $\mu \mathrm{mol} \mathrm{Cd} \mathrm{L}{ }^{-1}$, enquanto a oxidação protéica e a concentração de proteínas solúveis totais foram aumentadas somente em $400 \mathrm{e}$

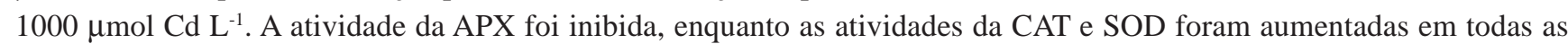
concentrações de Cd. A concentração de ácido ascórbico aumentou sob 400 e $1000 \mu \mathrm{mol} \mathrm{Cd} \mathrm{L-1}$, enquanto a de grupos tióis não-protéicos aumentou em todas as concentrações de Cd. Os resultados evidenciam a importância do sistema antioxidante enzimático e não-enzimático na resposta à toxicidade de cádmio em plântulas de pepino.

Palavras-chave: ácido ascórbico, enzimas antioxidantes, Cucumis sativus, metal pesado, oxidação protéica, peroxidação lipídica

\section{INTRODUCTION}

Cadmium (Cd) is one of the most important metals in terms of food-chain contamination, because it is readily taken up by the cells of different plant species (GomesJunior et al., 2006; Liu et al., 2007). In fact, at least $70 \%$ of the Cd intake by humans is originated from plant foods
(Wagner, 1993). Consequently, today, environment pollution by $\mathrm{Cd}$ is a growing concern in the research community.

Cadmium has been shown to cause many morphological, physiological, biochemical and structural changes in plants, such as growth inhibition, water imbalance and inhibition of seed germination (Benavides 
et al., 2005; Mishra et al., 2006a).

Certain heavy metals such as copper and iron can be toxic through their participation in redox cycles like Fenton and/or Haber-Weiss reactions. In contrast, Cd is a non-redox metal unable to perform single electron transfer reactions, and does not produce reactive oxygen species (ROS) such as the superoxide anion $\left(\mathrm{O}_{2}{ }^{-}\right)$, singlet oxygen $\left({ }^{1} \mathrm{O}_{2}\right)$, hydrogen peroxide $\left(\mathrm{H}_{2} \mathrm{O}_{2}\right)$ and hydroxyl radical $\left(\mathrm{OH}^{\circ}\right)$, but generates oxidative stress by interfering with the antioxidant defense system (Benavides et al., 2005; Gratão et al., 2005).

In plants, ROS are produced continuously as byproducts of various metabolic pathways that are localized in different cellular compartments (Gratão et al., 2005), but under stressful conditions, their formation might be in excess of antioxidant scavenging capacity, thus creating oxidative stress by reaction and damage to all biomolecules, especially proteins, due to the higher rate constants of the reaction of the superoxide anion with amino acid side chains (Davies, 2003). In addition, one of the most damaging effects of oxygen cytotoxic species and their products in cells is the peroxidation of membrane lipids and ion leakage (Gratão et al., 2005; Lee et al., 2007).

To control the level of ROS and to protect the cells, plants possess low molecular weight antioxidants (ascorbic acid, reduced glutathione, carotenoids, toco-pherols) and antioxidant enzymes such as superoxide dismutase (SOD; E.C. 1.15.1.1), ascorbate peroxidase (APX; E.C. 1.11.1.11) and catalase (CAT; E.C. 1.11.1.6) that scavenge ROS (Gratão et al., 2005). Superoxide dismutase is the major superoxide radical scavenger and its enzymatic action results in $\mathrm{H}_{2} \mathrm{O}_{2}$ and $\mathrm{O}_{2}$ formation. The product of SOD activity $\left(\mathrm{H}_{2} \mathrm{O}_{2}\right)$ is still toxic and must be eliminated by conversion to $\mathrm{H}_{2} \mathrm{O}$ in subsequent reactions. CAT and several classes of peroxidases like APX then scavenge the $\mathrm{H}_{2} \mathrm{O}_{2}$ produced (Benavides et al., 2005; Gratão et al., 2005).

The ascorbate-glutathione cycle seems to be a mechanism of great importance in controlling the cellular redox status, especially after application of heavy metals (Tiryakioglu et al., 2006; Liu et al., 2007). Ascorbic acid (AsA) is a primary as well as a secondary antioxidant. As secondary antioxidant it plays an important role in the regeneration of $\alpha$-tocopherol (Foyer and Noctor, 2005). In view of the multiple roles of ascorbate, changes in its concentration may have important consequences for cellular and metabolic regulation (Noctor et al., 2000). Also, non-protein thiol groups, especially glutathione, exert several important roles in protection of plants from environmental stress factors, especially in the case of $\mathrm{Cd}$ toxicity (Gratão et al., 2005; Tiryakioglu et al., 2006).

Cucumber is an important crop plant and was selected for study because it can be used as an indicator species to assess ecotoxicity of soils polluted by contaminants (Cargnelutti et al., 2006; Pereira et al., 2006) and also due to the insufficient information available on Cd toxicity in this species. In order to obtain more information on the mechanisms involved in the plant response to this metal, in the present study we focused on the effects of Cd on lipid peroxidation, electrolyte leakage, protein oxidation, APX, CAT and SOD activities, and AsA, non-protein thiol groups and total soluble protein concentrations.

\section{MATERIAL AND METHODS}

Plant material and growth conditions: Seeds of cucumber (Cucumis sativus L. cv. Aodai) obtained from Feltrin Ltd. (Santa Maria, Rio Grande do Sul State, Brazil) were germinated in glass recipients $(100 \mathrm{~mL})$ containing $15 \mathrm{~mL}$ of medium with four $\mathrm{Cd}$ concentrations as $\mathrm{CdCl}_{2}(0,100,400$,

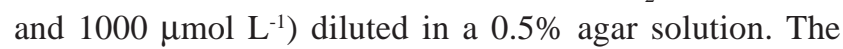
solution containing agar was heated and the cadmium solution was then added. No nutritive solution was added to the agar. The seedlings made use of the seed-stored reserves in the initial stage of development; it should be mentioned that seedlings (up to 10-d-old) did not suffer from any nutrient deficiency, as found in a preliminary experiment [see also Pereira et al. (2006)]. From preliminary analyses on the effect of several Cd concentrations (0-100 $\mu \mathrm{M})$ on cucumber seedlings it was noted that only the highest concentration led to decreases in growth; thus such a concentration was used in the present experiments. The medium $\mathrm{pH}$ was adjusted to 5.5. Each experimental unit consisted of six seeds, totalizing 15 replicates per treatment. The seedlings were maintained in a growth chamber with controlled temperature $\left(25 \pm 1^{\circ} \mathrm{C}\right)$ and photoperiod $(16 \mathrm{~h}$ light; light intensity of $35 \mu \mathrm{mol} \mathrm{m}^{-2} \mathrm{~s}^{-1}$ at the plant level).

Growth analysis: Cucumber growth was determined by measuring the length of the root system (Tennant, 1975) and the total dry weight (plants were left at $65^{\circ} \mathrm{C}$ to a constant weight). 
Metal determination: Approximately $0.05 \mathrm{~g}$ of roots and shoot were digested with $4 \mathrm{~mL} \mathrm{HNO}_{3}$ using the following stages of heating: a) $50^{\circ} \mathrm{C}$ for $1 \mathrm{~h}$; b) $80^{\circ} \mathrm{C}$ for $1 \mathrm{~h}$; and $120^{\circ} \mathrm{C}$ for $1 \mathrm{~h}$ in a digester block (Velp, Italy). The samples were then diluted to $50 \mathrm{~mL}$ with high-purity water. Concentrations of Cd were determined using an atomic absorption spectrometer (model AAS 5 EA, Analytic, Jena, Germany) equipped with a transversely heated graphite furnace and an autosampler (MPE 5) (Iyengar et al., 1997).

Estimation of lipid peroxidation: The concentration of peroxides was determined as malondialdehyde (MDA) accumulation by the thiobarbituric acid (TBA) reaction as described by El-Moshaty et al. (1993). The plants were homogenized in $0.2 \mathrm{~mol} \mathrm{~L}^{-1}$ citrate-phosphate buffer, $\mathrm{pH}$ 6.5 , at a proportion of 1:20 (w/v). The homogenate was filtered through two layers of filter paper and then centrifuged at $20,000 \mathrm{~g}$ at $4^{\circ} \mathrm{C}$ for $15 \mathrm{~min}$. One milliliter of the supernatant fraction was added to an equal volume of $20 \%$ TCA containing $0.5 \%$ TBA. Tubes were placed in a $95^{\circ} \mathrm{C}$ water-bath for $40 \mathrm{~min}$, and then immediately cooled on ice for $15 \mathrm{~min}$. Samples were centrifuged at $10,000 \mathrm{~g}$ for $15 \mathrm{~min}$. The absorbance of the supernatant at $532 \mathrm{~nm}$ was read and corrected for unspecific turbidity by subtracting the value at $600 \mathrm{~nm}$.

Electrolyte leakage percentage (ELP) measurement: The ELP was measured using an electrical conductivity meter following Lutts et al. (1996), with some modifications. Seedling samples were washed with distilled water to remove surface contamination, weighed into 5-g portions and placed in individual stoppered vials containing $50 \mathrm{~mL}$ of distilled water. These samples were incubated at $25^{\circ} \mathrm{C}$ on a shaker (100 rpm) for $24 \mathrm{~h}$. Electrical conductivity of the bathing solution (EC1) was read after incubation. Samples were then placed in thermostatic water-bath at $95^{\circ} \mathrm{C}$ for $15 \mathrm{~min}$ and the second reading (EC2) was determined after cooling the bathing solutions to $25^{\circ} \mathrm{C}$. The ELP was calculated as EC1/EC2.

Protein oxidation: The reaction of carbonyls with 2,4dinitrophenylhydrazine (DNPH) was used to determine the amount of protein oxidation, as described by Levine et al. (1990). Cucumber seedlings were homogenized in a $25 \mathrm{mmol} \mathrm{L}^{-1} \mathrm{~K}$-phosphate buffer containing $10 \mathrm{~mL} \mathrm{~L}^{-1}$ Triton X-100, pH 7.0, at a proportion of 1:5 (w/v). The homogenate was centrifuged at $13,000 \mathrm{~g}$ for $30 \mathrm{~min}$ at $4^{\circ} \mathrm{C}$. After the DNPH-reaction, the carbonyl concentration was calculated by absorbance at $370 \mathrm{~nm}$, using the molar extinction coefficient $21 \times 10^{3} \mathrm{mM} \mathrm{cm}^{-1}$.

Superoxide dismutase (SOD; E.C. 1.15.1.1) assay: The activity of SOD was assayed according to Misra and Fridovich (1972). About $200 \mathrm{mg}$ of cucumber seedlings were homogenized in $5 \mathrm{~mL}$ of $100 \mathrm{mmol} \mathrm{L}^{-1} \mathrm{~K}$-phosphate buffer (pH 7.8) containing $0.1 \mathrm{mmol} \mathrm{L}^{-1}$ EDTA, $0.1 \%(\mathrm{v} / \mathrm{v})$ Triton X-100 and 2\% PVP (w/v). The extract was filtered and centrifuged at $22,000 \mathrm{~g}$ for $10 \mathrm{~min}$ at $4^{\circ} \mathrm{C}$, and the supernatant was used for assays. The assay mixture consisted of a total volume of $1 \mathrm{~mL}$, containing glycine buffer ( $\mathrm{pH}$ 10.5), $1 \mathrm{mmol} \mathrm{L}^{-1}$ epinephrine and enzyme material. Epinephrine was the last added component. Adrenochrome formation over the next 4 min was spectrophotometrically recorded at $480 \mathrm{~nm}$. One unit of SOD activity is expressed as the amount of enzyme required to cause $50 \%$ inhibition of epinephrine oxidation under the experimental conditions used. This method is based on the ability of SOD to inhibit the autoxidation of epinephrine at an alkaline $\mathrm{pH}$. Since the oxidation of epinephrine leads to the production of a pink adrenochrome, the rate of increase of absorbance at 480 $\mathrm{nm}$, which represents the rate of autoxidation of epinephrine, can be conveniently followed. The enzyme has been found to inhibit this radical-mediated process.

Catalase (CAT; 1.11.1.6) assay: Catalase activity were determined from cucumber seedlings homogenized in a solution containing $50 \mathrm{mmol} \mathrm{L}^{-1} \mathrm{KH}_{2} \mathrm{PO}_{4} / \mathrm{K}_{2} \mathrm{HPO}_{4}(\mathrm{pH} 7.0$ ), $10 \mathrm{~g} \mathrm{~L}^{-1} \mathrm{PVP}, 0.2 \mathrm{mmol} \mathrm{L}^{-1}$ EDTA and $10 \mathrm{~mL} \mathrm{~L}^{-1}$ Triton X-100, at a proportion of $1: 5(\mathrm{w} / \mathrm{v})$. The homogenate was centrifuged at $12,000 \mathrm{~g}$ for $20 \mathrm{~min}$ at $4^{\circ} \mathrm{C}$. The supernatant was used for determination of CAT activity according to the modified method of Aebi (1984). The disappearance of $\mathrm{H}_{2} \mathrm{O}_{2}$ was monitored by measuring the decrease in absorbance at $240 \mathrm{~nm}$ in a reaction mixture with a final volume of $2 \mathrm{~mL}$ containing $15 \mathrm{mmol} \mathrm{L}^{-1} \mathrm{H}_{2} \mathrm{O}_{2}$ in $50 \mathrm{mmol} \mathrm{L}^{-1}$ $\mathrm{KPO}_{4}$ buffer (pH 7.0) and $30 \mu \mathrm{L}$ of the extract.

Ascorbate peroxidase (APX; E.C. 1.11.1.11) assay: To determine the APX activity, cucumber seedlings were homogenized in $50 \mathrm{mmol} \mathrm{L}^{-1} \mathrm{~K}$-phosphate buffer containing $1 \mathrm{mmol} \mathrm{L}^{-1}$ EDTA and 2\% PVP (w/v), pH 7.8, at 
a proportion of $1: 3(\mathrm{w} / \mathrm{v})$. The homogenate was centrifuged at $13,000 \mathrm{~g}$ for $20 \mathrm{~min}$ at $4^{\circ} \mathrm{C}$, and the supernatant used for enzyme activity according to the modified method of Zhu et al. (2004). The reaction mixture in a total volume of $2 \mathrm{~mL}$ consisted of $25 \mathrm{mmol} \mathrm{L}^{-1}$ sodium phosphate buffer (pH 7.0), $0.1 \mathrm{mmol} \mathrm{L}^{-1}$ EDTA, $0.25 \mathrm{mmol}$ $\mathrm{L}^{-1}$ ascorbate, $1.0 \mathrm{mmol} \mathrm{L}^{-1} \mathrm{H}_{2} \mathrm{O}_{2}$ and $100 \mu \mathrm{L}$ extract. The $\mathrm{H}_{2} \mathrm{O}_{2}$-dependent oxidation of ascorbate was followed by a decrease in absorbance at $290 \mathrm{~nm}$ using the molar extinction coefficient $2.8 \mathrm{mM} \mathrm{cm}^{-1}$.

Ascorbic acid (AsA) and non-protein thiol group (NPSH) concentrations: Cucumber seedlings were homogenized in a solution containing $50 \mathrm{mmol} \mathrm{L}^{-1}$ Tris$\mathrm{HCl}$ and $10 \mathrm{~mL} \mathrm{~L}^{-1}$ Triton X-100 (pH 7.5) and centrifuged at $6,800 \mathrm{~g}$ for $10 \mathrm{~min}$. To the resulting supernatant $10 \%$ TCA was added at a proportion of $1: 1(\mathrm{v} / \mathrm{v})$ followed by centrifugation $(6,800 \mathrm{~g}$ for $10 \mathrm{~min})$ to remove protein. Determination of AsA was performed as described by Jacques-Silva et al. (2001). An aliquot of the sample (300 $\mu \mathrm{L}$ ) was incubated at $37^{\circ} \mathrm{C}$ in a medium containing $100 \mu \mathrm{L}$ TCA 13.3\%, $100 \mu \mathrm{L}$ deionized water and $75 \mu \mathrm{L}$ DNPH. The DNPH solution contained 2\% DNPH, 0.23\% thiourea, and $0.27 \% \mathrm{CuSO}_{4}$ diluted in $49 \% \mathrm{H}_{2} \mathrm{SO}_{4}$. After $3 \mathrm{~h}, 500 \mu \mathrm{L}$ of $65 \% \mathrm{H}_{2} \mathrm{SO}_{4}$ was added and samples were read at $520 \mathrm{~nm}$. A standard curve was constructed using $L(+)$ ascorbic acid. Non-protein thiols concentration was measured spectrophotometrically with Ellman's reagent (Ellman, 1959). An aliquot of the sample $(400 \mu \mathrm{L})$ was added to a medium containing $550 \mu \mathrm{L}$ of $1 \mathrm{~mol} \mathrm{~L}^{-1}$ Tris-HCl (pH 7.4). The developed color was read at $412 \mathrm{~nm}$ after the addition

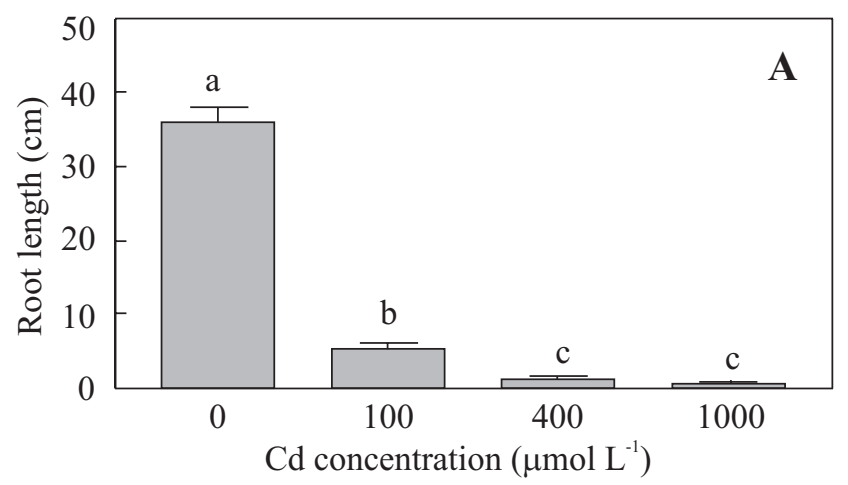

of $10 \mathrm{mmol} \mathrm{L}^{-1}$ 5-5-dithio-bis (2-nitrobenzoic acid) (DTNB) $(0.05 \mathrm{~mL})$. A standard curve using cysteine was used to calculate the concentration of thiol groups in samples.

Protein determination: In all the enzyme preparations, protein was measured by the Coomassie Blue method according to Bradford (1976) using BSA as standard.

Statistical analysis: The experiments were performed using a randomized design. The analyses of variance were computed on statistically significant differences determined based on the appropriate $F$-tests. The results are presented as means \pm S.D. of at least three independent replicates. The mean differences were compared using the Tukey test $(P<0.05)$. Three pools of five replicates each $(n=3)$ were taken for all analyses from each set of experiments.

\section{RESULTS}

Analysis of Cd concentration and seedling growth: Increasing $\mathrm{Cd}$ concentrations significantly enhanced $\mathrm{Cd}$ concentration in both roots and shoot. Relative to control plants, root length decreased significantly by $83 \%$ in

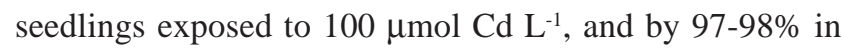

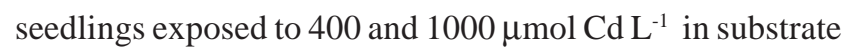
(Figure 1A). Furthermore, with increasing supply of Cd, the total dry weight showed a clear negative linear response. Total dry weight decreased 32\%, 47\% and 56\%, respectively,

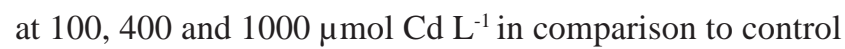
seedlings (Figure 1B).

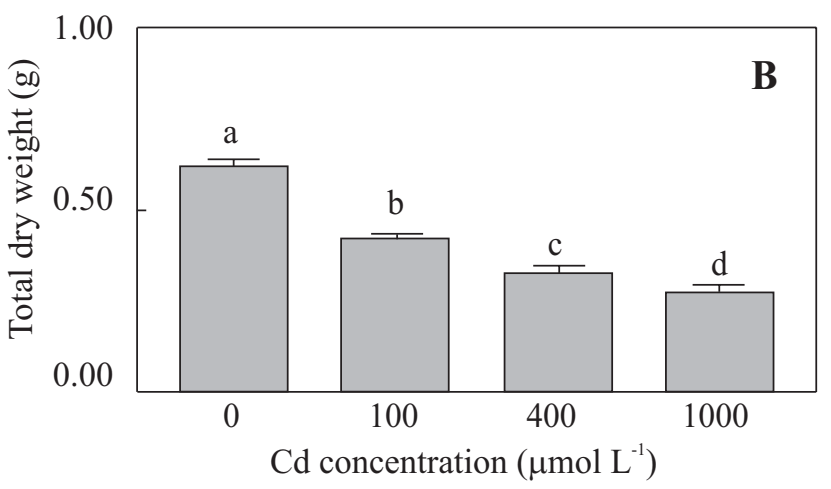

Figure 1. Effect of Cd at different concentrations on root length (A) and total dry weight (B) of 10-d-old cucumber seedlings. Vertical bars represent SD $(n=15)$. Different letters indicate significant difference among Cd concentrations (one-way ANOVA, Tukey test; $P<0.05$ ). 
Estimation of lipid peroxidation, ELP, protein oxidation and total soluble protein: The effect of $\mathrm{Cd}$ on cell membrane integrity was determined by evaluating MDA levels and ELP of plant tissues. Compared to control seedlings, a significant change (a 20.5\% decrease) in MDA concentration was noticed, but only at the lowest Cd concentration (100 $\left.\mu \mathrm{mol} \mathrm{L}^{-1}\right)$ (Figure 2A); conversely, only at the highest Cd supply $(1000 \mu \mathrm{mol} \mathrm{L}-1)$ a significant change (a 55\% increase) in ELP was found (Figure 2B).

Cucumber seedlings grown with Cd showed an increase in carbonyl formation, which nearly doubled at $1000 \mu \mathrm{mol} \mathrm{Cd} \mathrm{L}{ }^{-1}$ as compared to control plants (Figure 2C). Moreover, we observed that total soluble protein content was enhanced $54 \%$ and $87 \%$, respectively, at 400 and 1000 $\mu \mathrm{mol} \mathrm{Cd} \mathrm{^{-1 }}$ in comparison to control seedlings (Figure 2D).

Antioxidant enzymes activities: A sharp increase in SOD activity following exposure to $\mathrm{Cd}$ was noticed, but with no discernible pattern in relation to the Cd doses (Figure 3A). The activity of CAT increased at 100 and $400 \mu \mathrm{mol}$ $\mathrm{Cd} \mathrm{L}^{-1}$ (respectively $180 \%$ and $173 \%$ ), and then decreased at the highest Cd supply, although enzyme activity was significantly larger (80\%) than in control plants. (Figure
3B). On the other hand, APX activity significantly decreased by $61 \%, 85 \%$ and $79 \%$ in seedlings exposed to 100, 400 and $1000 \mu \mathrm{mol} \mathrm{Cd} \mathrm{L}^{-1}$ as compared to the control, respectively. No significant difference for APX activity at 400 and $1000 \mu \mathrm{mol} \mathrm{Cd} \mathrm{L}^{-1}$ was detected (Figure 3C).

Concentrations of AsA and NPSH: Cadmium treatment led to increased tissue AsA concentration, but only at $400 \mu \mathrm{mol}$ $\mathrm{Cd} \mathrm{L}^{-1}$ (49\%) and $1000 \mu \mathrm{mol} \mathrm{Cd} \mathrm{L^{-1 }}$ (63\%) (Figure 4A). Furthermore, NPSH concentration increased linearly with increasing Cd supply, as can be deduced from Figure 4B.

\section{DISCUSSION}

The environmental degradation, promoted mainly by anthropogenic action, has imposed strong pressure on the quality of ecosystems. The pollution of soil and water by a wide range of contaminants for both plants and animals has become a matter of great concern to researchers. In this sense, the elevated levels of heavy metals such as $\mathrm{Cd}$ in the environment are a reality today. Cd occurs naturally at a low concentration in the soil, but its level has been steadily increasing due to mining and
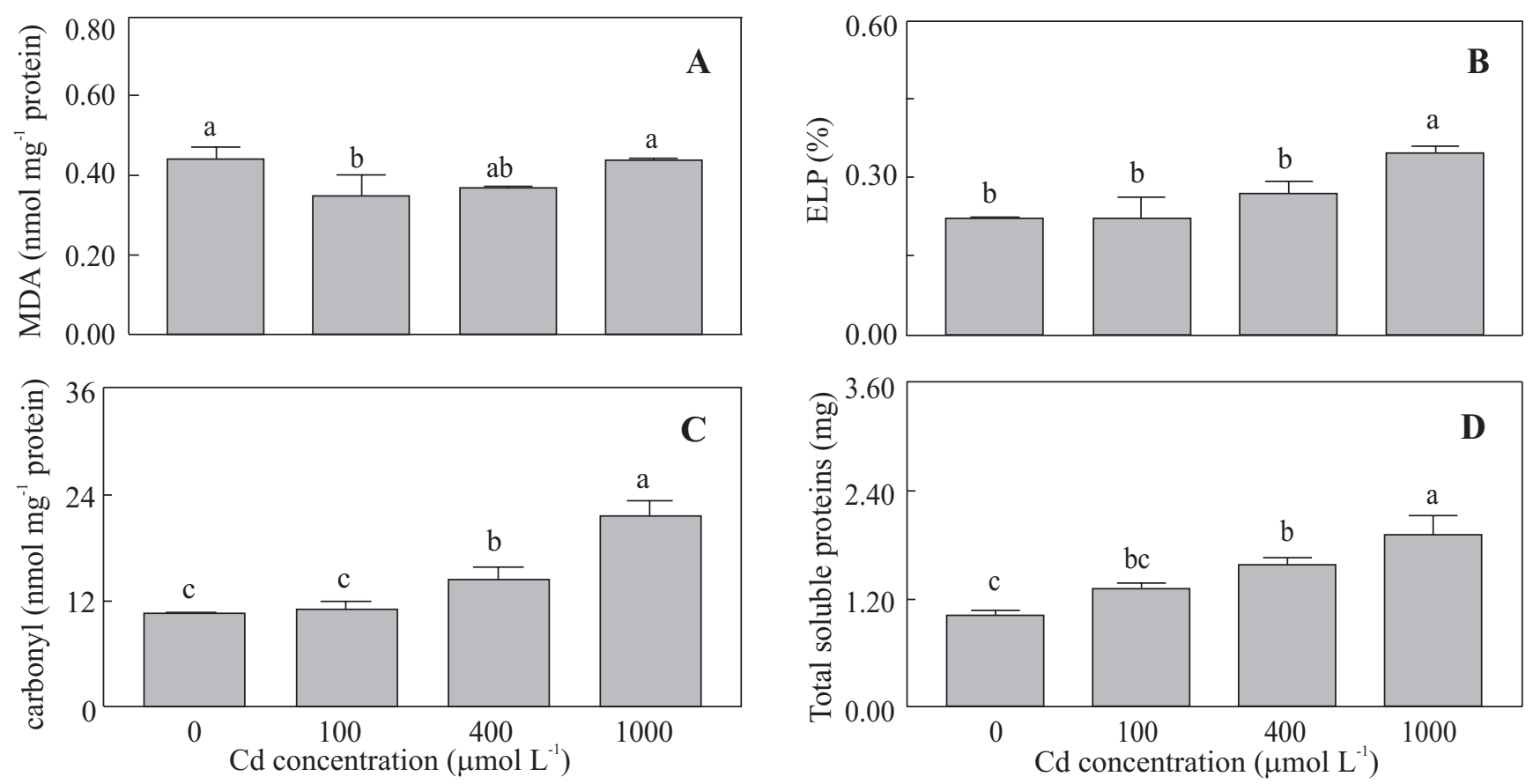

Figure 2. Effect of Cd at different concentrations on malondealdehyde (MDA) concentration (A), electrolyte leakage percentage (ELP) (B), protein oxidation (C), and total soluble proteins content (D) of 10-d-old cucumber seedlings. Statistics as in Figure 1. 

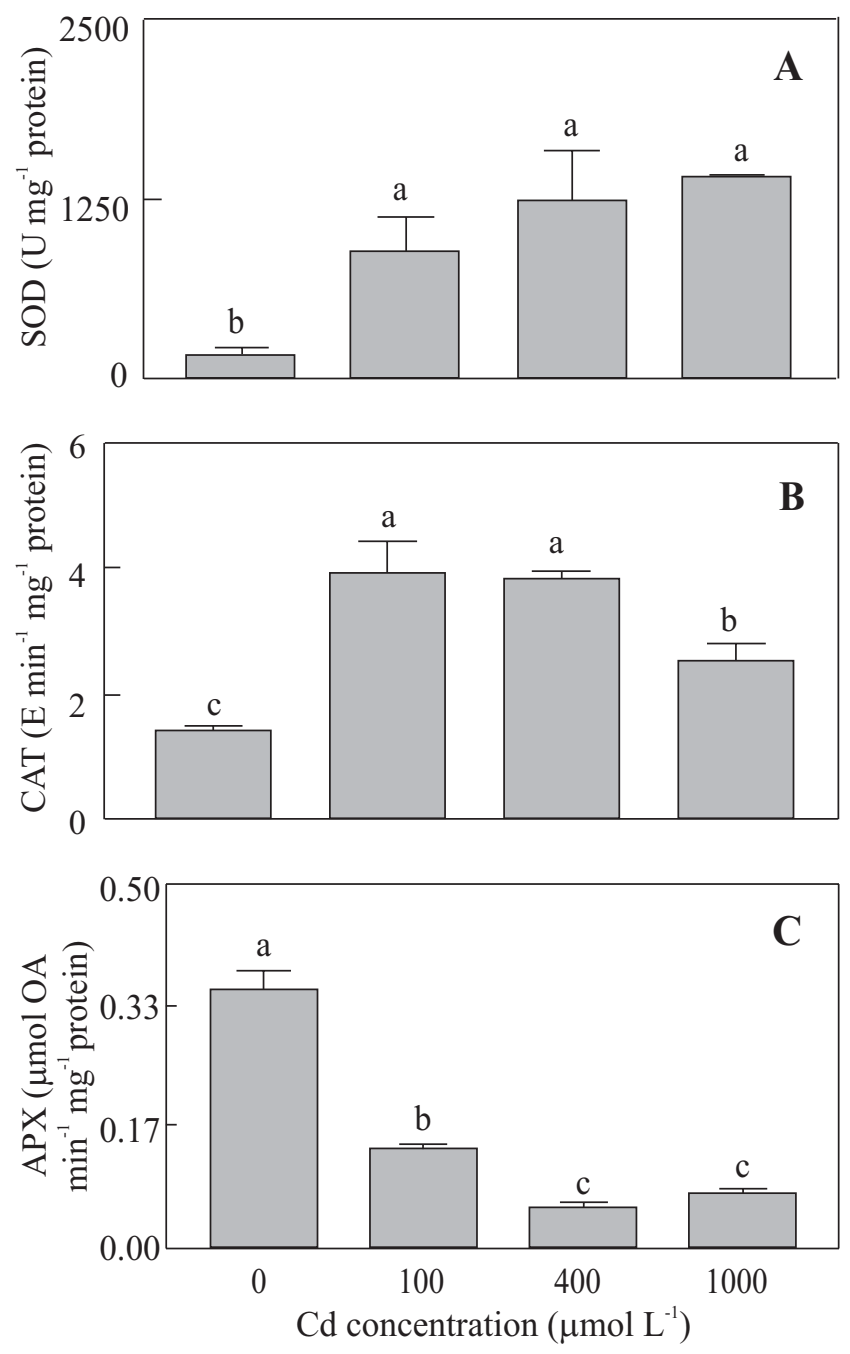

Figure 3. Effect of $\mathrm{Cd}$ at different concentrations on superoxide dismutase (SOD) (A), catalase (CAT) (B), and ascorbate peroxidases (APX) (C) activities of 10-d-old cucumber seedlings. OA = oxidized ascorbate. Statistics as in Figure 1.

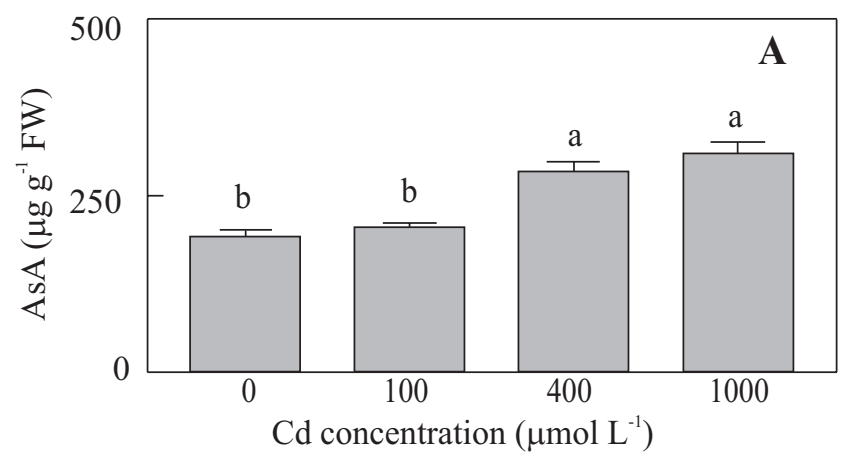

smelting, dispersal of sewage sludge and the use of Cdrich phosphate fertilizers (Wagner, 1993; Liu et al., 2007). The Cd concentrations used in our experiments (up to $1000 \mu \mathrm{mol} \mathrm{L}^{-1}$ ) are higher than those observed in polluted soils, but these concentrations were chosen to be suitable after preliminary tests in our laboratory and, as expected, increasing $\mathrm{Cd}$ concentrations significantly enhanced Cd concentration in roots and in shoot. However, cucumber accumulated significantly higher Cd concentration in roots than in shoot (J.F. Gonçalves et al., unpublished results). Furthermore, even at such high concentrations, potential differences among the plants so far analyzed have been observed in relation to their tolerance of Cd (Tiryakioglu et al., 2006; Ekmekçi et al., 2007).

The present study shows that seedlings of cucumber presented a significant decrease in root length and total dry weight at all Cd treatments. However, it should be noted that although both parameters were affected by Cd supply, the decrease in root length was stronger than in total dry weight. According to Tiryakioglu et al. (2006), the reason for high root sensitivity to $\mathrm{Cd}$ might be related to the fact that roots are the first organs to be in contact with $\mathrm{Cd}$, and hence accumulating $\mathrm{Cd}$ at much higher amounts than the shoot. Such decrease in growth of Cdexposed plants has also been reported in other investigations (Vitória et al., 2001; Ferreira et al., 2002; Zhang et al., 2002).

Despite being a non-redox metal, and thus not directly producing ROS (Benavides et al., 2005), Cd can interfere with antioxidant defense systems. Under stressful conditions the protective system can be overridden by a rapid production of large amounts of ROS, leading to

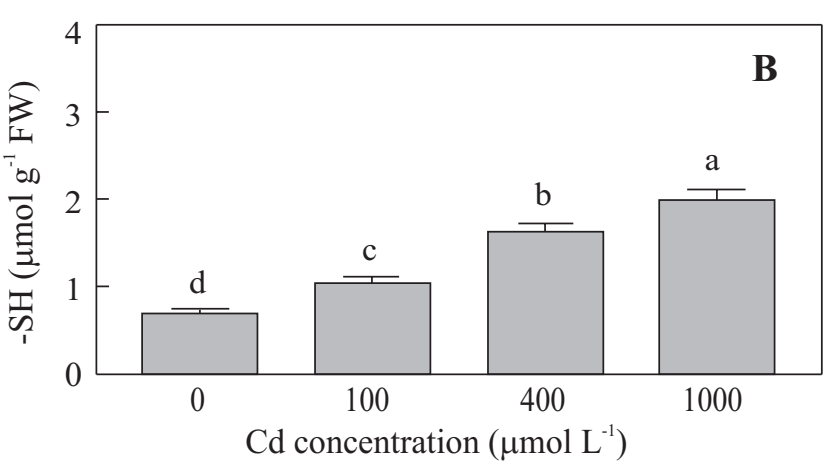

Figure 4. Effect of Cd at different concentrations on ascorbic acid (AsA) (A) and non-protein thiol groups concentrations (B) of 10-d-old cucumber seedlings. Statistics as in Figure 1. 
various structural modifications in proteins (Cargnelutti et al., 2006). These oxidative modifications are characterized by the formation of carbonyl derivatives on side chains of histidine, arginine, lysine, and proline residues (Shacter et al., 1994). Our data demonstrated that the seedling exposure to $\mathrm{Cd}$ exceeding $100 \mu \mathrm{mol} \mathrm{\textrm {L } ^ { - 1 }}$ caused a remarkable increase in carbonyl formation, indicating that $\mathrm{Cd}$ promoted a high protein oxidation. This result is in agreement with that reported by Arvind and Prasad (2005) and Rellán-Álvarez et al. (2006) who noticed carbonyl accumulation in Ceratophyllum demersum and Zea mays plants exposed to Cd. In addition to oxidation of proteins, an increased total soluble protein content in cucumber seedlings exposed to $\mathrm{Cd}$ concentrations was found. In another study, Cargnelutti et al. (2006) showed that Hg-treated cucumbers presented increased total soluble protein content and protein oxidation. Increase in protein content is possible due to de novo synthesis of stress proteins provoked by metal exposure (Verma and Dubey, 2003). These stress proteins may constitute enzymes involved in GSH and phytochelatin biosynthesis and those required for Krebs cycle, as well as antioxidants and some heat shock proteins (Mishra et al., 2006b).

Measurement of MDA, a common product of lipid peroxidation, is routinely used as an index of lipid peroxidation under stressful conditions (Mishra et al., 2006a; Lee et al., 2007). In the present study the MDA

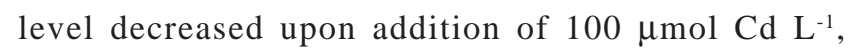
indicating lower lipid peroxidation. We suggest that the decrease in MDA concentration in the whole seedling may be due to a decrease in polyunsaturated fatty acid concentration relative to saturated fatty acids, which has also been reported in cucumber under stressful conditions (Kramer et al., 1991). Furthermore, Sinha et al. (1996) reported that a low Hg concentration lowered both the MDA and polyunsaturated fatty acid concentrations in root and leaf tissues of Bacopa monnieri. Moreover, membrane damage was evaluated indirectly with conductivity measurements of solute leakage from cells (Ekmekçi et al., 2007). Interestingly, in the present study the ELP was only increased upon addition of $\mathrm{Cd}$ at the highest level. Increased ELP has been reported by other investigations working with other plant species exposed to a range of Cd concentrations (e.g., Mishra et al., 2006a; Ekmekçi et al., 2007 and Lee et al., 2007). Cadmium, like other class B metals, has strong affinity towards nitrogen- and sulfur-containing ligands and proteins. So, it forms bridges within proteins leading to distorted membrane ion channels and leakage of ions (Mishra et al., 2006a).

In order to scavenge ROS and to avoid oxidative damage, plants possess several antioxidant enzymes. Superoxide dismutase, the first enzyme in the detoxifying process, converts superoxide radicals to $\mathrm{H}_{2} \mathrm{O}_{2}$ at a very fast rate (Gratão et al., 2005). The enhanced SOD activity we observed is consistent with previous reports in which other plant species were treated with Cd (Vitória et al., 2001; Gomes-Junior et al., 2006). Increase in SOD activity may be linked to an increase in superoxide radical formation as well as to de novo synthesis of enzyme protein (Verma and Dubey, 2003), which in turn may be associated with an induction of genes of SOD by superoxide-mediated signal transduction (Fatima and Ahamad, 2005). Due to the action of SOD, or by direct formation in biochemical pathways like photorespiration, $\mathrm{H}_{2} \mathrm{O}_{2}$ concentration is expected to increase inside the cell. Although $\mathrm{H}_{2} \mathrm{O}_{2}$ takes part in several important functions in plant cells (Foyer and Noctor, 2005), control of its build-up is essential to prevent oxidative damage to membranes and proteins. In fact, the increased CAT activity as found herein, which can be associated with $\mathrm{H}_{2} \mathrm{O}_{2}$ scavenging, was also observed by Vitória et al. (2001) in Raphanus sativus and by Gomes-Júnior et al. (2006) in Coffea arabica under Cd-stress conditions. This increase suggests a compensatory mechanism of defense against oxidative stress caused by toxic metal concentrations and can be explained by increase in its substrate to maintain the level of $\mathrm{H}_{2} \mathrm{O}_{2}$ as an adaptive mechanism of the plants (Cargnelutti et al., 2006). Furthermore, the combined action of CAT and SOD is critical in mitigating the effects of oxidative stress, since their roles in the cell metabolism are complementary (Benavides et al., 2005). In this sense, it is interesting to note that both SOD and CAT activities increased in Cdtreated cucumbers and that it is widely agreed that plants resist oxidative stress by increasing components of their intrinsic defensive system (Benavides et al., 2005).

In this work, APX activity, a $\mathrm{H}_{2} \mathrm{O}_{2}$-scavenger that belongs to the ascorbate-glutathione cycle, was inhibited at all Cd concentrations tested. Such a decrease has also been reported in some Cd-treated plants (Zhang et al., 2002; Gomes-Júnior et al., 2006). The reduction in APX activity may be due to GSH depletion and a subsequent 
reduction in the ascorbate-glutathione cycle (GomesJúnior et al., 2006). The reduction in GSH could be caused by an increased rate of phytochelatin synthesis induced by Cd ions (Gomes-Júnior et al., 2006). Ascorbate peroxidase could be responsible for the fine modulation of ROS for signaling, and its reduced activity would lead to a deleterious imbalance in ROS production and scavenging (Gomes-Júnior et al., 2006), leading to signaling alterations in other physiological processes in cucumber seedlings. Furthermore, the decreased activity of APX was apparently compensated for by the increased activity of other $\mathrm{H}_{2} \mathrm{O}_{2}$-degrading enzymes like CAT (Mishra et al., 2006a).

The response of antioxidant enzymes to Cd can vary among species and among different tissues (Vitória et al., 2001; Ekmekçi et al., 2007). Either activation or inhibition of APX, CAT and SOD activities have been related to effects of $\mathrm{Cd}$ toxicity in plants. The reason for such inconsistent results with the effects of $\mathrm{Cd}$ seems to be due to differences in the plant organs studied (root, stem, leaf), duration and concentration of Cd utilized and plant species (or genotypes) under investigation (Tiryakioglu et al., 2006).

In fact, in this work only changes in enzymatic activities, such as SOD, CAT or APX were detected, but not alterations of enzyme expression. The different levels of enzymatic activity are not exclusively dependent on enzyme synthesis, but on various other factors as well. Thus, in futures studies it will be necessary to analyze the effects of $\mathrm{Cd}$ on antioxidant enzymes activities by native polyacrylamide gel electrophoresis to verify possible differences in activity among specific isoenzymes as shown by some authors (Vitória et al., 2001; Gomes-Júnior et al., 2006; Ferreira et al., 2007; Lee et al., 2007). Furthermore, it would be interesting to evaluate the activity of other enzymes involved in the antioxidant system, such as glutathione reductase, in order to further understand the oxidative stress caused by $\mathrm{Cd}$ in cucumber.

To understand the contribution of the non-enzymatic antioxidants in the response of cucumber seedlings to Cd toxicity, we examined their AsA and NPSH concentrations. Cucumber AsA concentration was enhanced at the two highest Cd concentrations compared to the control, indicating that AsA is involved in antioxidant response of this plant to Cd toxicity. Similarly to our results, other investigations have shown increased AsA for other plant species exposed to Cd (Tiryakioglu et al., 2006; Liu et al.,
2007). Of the antioxidants found in plants, AsA is the most abundant and has diverse physiological roles (Noctor, 2006), being a substrate for APX in addition to directly scavenging superoxide, hydroxyl radicals, and singlet oxygen (Chen and Gallie, 2004). With regard to NPSH, its increased concentration at all Cd concentrations is also consistent with other investigations which have shown increased NPSH in plants exposed to Cd (Mishra et al., 2006a,b; Tiryakioglu et al., 2006). Such enhancement may be due to an increase of phytochelatins and is correlated with the observed reduction in APX activity. The synthesis of phytochelatins could mitigate Cd toxicity by complexing the metal and is an important mechanism of plant adaptation to long periods of metal exposure (Romero-Puertas et al., 2007). This increase in the level of thiols may be due to stimulation of enzymes of the sulfate reduction pathway such as adenosine 5'-phosphosulfate reductase and serine acetyltransferase (Noctor et al., 1998). The enhancement of AsA levels together with the marked increase in NPSH concentration possibly reflects a defense reaction to enhanced production of ROS (Tiryakioglu et al., 2006) and indicates the ability of cucumber to tolerate the cellular metal load.

We showed that MDA concentration decreased upon addition of the lowest Cd concentration whereas ELP increased in plants exposed to highest Cd supply, demonstrating that plasma membrane structure was affected by $\mathrm{Cd}$ in the substrate. Also, Cd strongly interfered with the oxidative metabolism of cucumber seedlings by increasing protein oxidation and AsA, nonprotein thiol groups and total soluble protein content. Besides, the enzymes SOD and CAT, rather than APX, could act as important components of the antioxidant defense system mechanisms to cope with metal-induced oxidative injury. Nonetheless, despite these Cd-induced changes, cucumber growth was extremely decreased in the presence of this metal demonstrating that other enzymes or metabolites not evaluated in this work could have been affected by Cd stress.

Acknowledgements: The authors wish to thank the Conselho Nacional de Desenvolvimento Científico e Tecnológico (CNPq), Coordenação e Aperfeiçoamento de Pessoal de Nível Superior (CAPES) and Fundação de Amparo à Pesquisa do Estado do Rio Grande do Sul (FAPERGS). 


\section{REFERENCES}

Aebi H (1984) Catalase in vitro. Methods Enzymol. 105:121-126.

Arvind P, Prasad MNV (2005) Cadmium-zinc interactions in a hydroponic system using Ceratophyllum demersum L.: adaptative ecophysiology, biochemistry and molecular toxicology. Braz. J. Plant Physiol. 17:3-20.

Benavides MP, Gallego SM, Tomaro ML (2005) Cadmium toxicity in plants. Braz. J. Plant Physiol. 17:21-34.

Bradford M (1976) A rapid and sensitive method for quantification of microgram quantities of protein utilizing the principle of protein-dye binding. Anal. Biochem. 72:248-254.

Cargnelutti D, Tabaldi LA, Spanevello RM, Jucoski GO, Battisti V, Redin M, Linares CEB, Dressler VL, Flores EMM, Nicoloso FT, Morsch VM, Schetinger MRC (2006) Mercury toxicity induces oxidative stress in growing cucumber seedlings. Chemosphere 65:999-1006.

Chen Z, Gallie DR (2004) The ascorbic acid redox state controls guard cell signaling and stomatal movement. Plant Cell 16:1143-1162.

Davies MJ (2003) Singlet oxygen-mediated damage to proteins and its consequences. Biochem. Biophys. Res. Comm. 305:761-770.

Ekmekçi Y, Tan Yolaç D, Ayhan B (2007) Effects of cadmium on antioxidant enzyme and photosynthetic activities in leaves of two maize cultivars. J. Plant Physiol. in press.

Ellman GL (1959) Tissue sulfhydryl groups. Arch. Biochem. Biophys. 82:70-77.

El-Moshaty FIB, Pike SM, Novacky AJ, Sehgal OP (1993) Lipid peroxidation and superoxide production in cowpea (Vigna unguiculata) leaves infected with tobacco ringspot virus or southern bean mosaic virus. Physiol. Mol. Plant Pathol. 43:109-119.

Fatima RA, Ahmad M (2005) Certain antioxidant enzymes of Allium cepa as biomarkers for the detection of toxic heavy metals in wastewater. Sci. Total Environ. 346:256-273.

Ferreira RR, Fornazier RF, Vitória AP, Lea PJ, Azevedo RA (2002) Changes in antioxidant enzyme activities in soybean under cadmium stress. J. Plant Nutr. 25:327-342.

Foyer CH, Noctor G (2005) Redox homeostasis and antioxidant signaling: a metabolic interface between stress perception and physiological responses. Plant Cell 17:1866-1875.
Gomes-Júnior RA, Moldes CA, Delite FS, Pompeu GB, Gratão PL, Mazzafera P, Lea PJ, Azevedo RA (2006) Antioxidant metabolism of coffee cell suspension cultures in response to cadmium. Chemosphere 65:1330-1337.

Gratão PL, Polle A, Lea PJ, Azevedo RA (2005) Making the life of heavy-metal stressed plants a little easier. Funct. Plant Biol. 32:481-494.

Iyengar GV, Subramanian KS, Woittiez JRW (1997) Elemental Analysis of Biological Samples. Principles and Practice. CRC Press, Boca Raton.

Jacques-Silva MC, Nogueira CW, Broch LC, Flores EMM, Rocha JBT (2001) Diphenyl diselenide and ascorbic acid changes deposition of selenium and ascorbic acid in liver and brain of mice. Pharmacol. Toxicol. 88:119-125.

Kramer GF, Norman HA, Krizek DT, Mirecki RM (1991) Influence of UV-B radiation on polyamines, lipid peroxidation and membrane lipids in cucumber. Phytochemistry 30:2101-2108.

Lee S-H, Ahsan N, Lee K-W, Kim D-H, Lee D-G, Kwak S-S, Kwon S-Y, Kim T-H, Lee B-H (2007) Simultaneous overexpression of both CuZn superoxide dismutase and ascorbate peroxidase in transgenic tall fescue plants confers increased tolerance to a wide range of abiotic stresses. J. Plant Physiol. in press.

Levine RL, Garland D, Oliver CN, Amici A, Climent I, Lenz AG, Ahn BW, Shaltiel S, Stadtman ER (1990) Determination of carbonyl concentration in oxidatively modified proteins. Meth. Enzymol. 186:464-478.

Liu Y, Wang X, Zeng G, Qu D, Gu J, Zhou M, Chai L (2007) Cadmium-induced oxidative stress and response of the ascorbate-glutathione cycle in Bechmeria nivea (L.) Gaud. Chemosphere 69:99-107.

Lutts S, Kinet JM, Bouharmont J (1996) NaCl-induced senescence in leaves of rice (Oriza sativa L.) cultivar differing in salinity resistance. Ann. Bot. 78:389-398.

Mishra S, Srivastava S, Tripathi RD, Govindarajan R, Kuriakose SV, Prasad MNV (2006a) Phytochelatin synthesis and response of antioxidants during cadmium stress in Bacopa monnieri L. Plant Physiol. Biochem. 44:25-37.

Mishra S, Srivastava S, Tripathi RD, Kumar R, Seth CS, Gupta DK (2006b) Lead detoxification by coontail (Ceratophyllum demersum L.) involves induction of phytochelatins and antioxidant system in response to its accumulation. Chemosphere 65:1027-1039. 
Misra HP, Fridovich I (1972) The role of superoxide anion in the autoxidation of epinephrine and simple assay for superoxide dismutase. J. Biol. Chem. 244:6049-6055.

Noctor G, Arisi ACM, Jouanin L, Kunert KJ, Rennenberg H, Foyer CH (1998) Glutathione biosynthesis, metabolism and relationship to stress tolerance explored in transformed plants. J. Exp. Bot. 49:623647.

Noctor G, Veljovic-Jovanovic S, Foyer CH (2000) Peroxide processing in photosynthesis: antioxidant coupling and redox signaling. Phil. Trans. R. Soc. London B 355:1465-1475.

Noctor G (2006) Metabolic signalling in defence and stress: the central roles of soluble redox couples. Plant Cell Environ. 29:409-425.

Pereira LB, Tabaldi LA, Gonçalves JF, Jucoski GO, Pauletto MM, Weis SN, Nicoloso FT, Borher D, Rocha JBT, Schetinger MRC (2006) Effect of aluminum on $\delta$ aminolevulinic acid dehydratase (ALA-D) and the development of Cucumber (Cucumis sativus). Environ. Exp. Bot. 57:106-115.

Rellán-Álvarez R, Ortega-Villasante C, Álvarez-Fernández A, del Campo FF, Hernández LE (2006) Stress responses of Zea mays to cadmium and mercury. Plant Soil 279:41-50.

Romero-Puertas MC, Corpas FJ, Rodríguez-Serrano M, Gómez M, del Río LA, Sandalio LM (2007) Differential expression and regulation of antioxidative enzymes by cadmium in pea plants. J. Plant Physiol. 164:1346-1357.
Shacter E, Willians JA, Lim M, Levine RL (1994) Differential susceptibility of plasma proteins to oxidative modification: examination by western blot immunoassay. Free Rad. Biol. Med. 17:429-437.

Sinha S, Gupta M, Chandra P (1996) Bioaccumulation and biochemical effects of mercury in the plant Bacopa monnieri L. Environ. Toxicol. Water Qual. 11:105-112.

Tennant D (1975) A test of a modified line intersect method of estimating root length. J. Ecol. 63:995-1001.

Tiryakioglu M, Eker S, Ozkutlu F, Husted S, Cakmak I (2006) Antioxidant defense system and cadmium uptake in barley genotypes differing in cadmium tolerance. J. Trace Elem. Med. Biol. 20:181-189.

Verma S, Dubey RS (2003) Lead toxicity induces lipid peroxidation and alters the activities of antioxidant enzymes in growing rice plants. Plant Sci. 164:645-655.

Vitória AP, Lea PJ, Azevedo RA (2001) Antioxidant enzymes responses to cadmium in radish tissues. Phytochemistry 57: 701-710.

Wagner GJ (1993) Accumulation of cadmium in crop plants and its consequences to human health. Adv. Agron. 51:173-212.

Zhang F, Shi W, Jin Z, Shen Z (2002) Response of antioxidative enzymes in cucumber chloroplasts to cadmium toxicity. J. Plant Nutr. 26:1779-1788.

Zhu Z, Wei G, Li J, Qian Q, Yu J (2004) Silicon alleviates salt stress and increases antioxidant enzymes activity in leaves of salt-stressed cucumber (Cucumis sativus L.). Plant Sci. 167:527-533. 